Acta Technologica Agriculturae 4

Nitra, Slovaca Universitas Agriculturae Nitriae, 2019, pp. 122-127

\title{
THE INFLUENCE OF SELECTED EXTERNAL FACTORS ON TEMPERATURE OF PHOTOVOLTAIC MODULES
}

\author{
Matúš BILČÍK*, Monika BOŽIKOVÁ, Martin MALÍNEK \\ Slovak University of Agriculture in Nitra, Slovak Republic
}

\begin{abstract}
The article deals with the impact of selected external factors on the temperature of photovoltaic module surfaces. Primary aim of this research is creation of temperature model for photovoltaic module, which would be usable under the real climatic conditions in Central Europe region. Fully autonomous measuring system was designed and created for temperature monitoring of different parts of photovoltaic modules. The measuring system consists of 24 temperature sensors, voltage inverter, control unit, transfer modules, receiver modules and temperature measuring module. The experiments were performed on photovoltaic modules installed on the roof of the University of Life Sciences in Prague during summer 2018. The temperature of photovoltaic modules significantly depends on the climatic conditions, which were monitored by the weather station. The temperature and the solar radiation dependencies for polycrystalline and monocrystalline photovoltaic modules were obtained in experiments conducted. The temperature relations were measured for different parts of photovoltaic module - active parts of photovoltaic module, frame, non-active parts of photovoltaic module, as well as ambient temperature. Final mathematical description of polynomial graphical dependencies was obtained after application of fitting procedure and regression analysis.
\end{abstract}

Keywords: temperature; solar radiation; dependence; measuring system; temperature sensor

Solar energy can be converted into electrical energy by using photovoltaics (Chander et al., 2015). Possibilities of photovoltaic (PV) system application have been described in publications by Čorba et al. (2009) and Milićević et al. (2012). The operating temperature of PV module depends on several factors, such as: solar radiation; ambient temperature; wind speed and direction; module material composition; mounting structure. These relations have been presented by authors Amstrong and Hurley (2010), Malínek et al. (2018), Bilčík and Božiková (2018) and Libra et al. (2017). All aforementioned conditions have a significant influence on PV cell energy production; however, the most crucial factor is temperature. The effects of the PV module operating temperature on the output efficiency have been described by Jones and Underwood (2001), Schott (1985), Servant (1985), Kafui et al. (2018) and their research results have shown that increasing temperature has a negative impact on the amount of power available. On the basis of the presented facts, the paper at hand deals with the analysis of PV module temperature. Experiments were conducted on the PV system with polycrystalline and monocrystalline PV modules at the Czech University of Life Sciences in Prague (Czech Republic). The temperature of PV module was monitored by fully autonomous measuring system with 24 temperature sensors. The climatic data were obtained from weather station at the same location as the PV system. under the real climatic conditions

\section{Material and methods}

In terms of external factors having significant influence on the PV system operating parameters, temperature can be considered the most important. There are multiple different ways for the temperature measurement to be realized under the external conditions. In case of this research, autonomous measuring system was designed and constructed (Fig. 1). This system

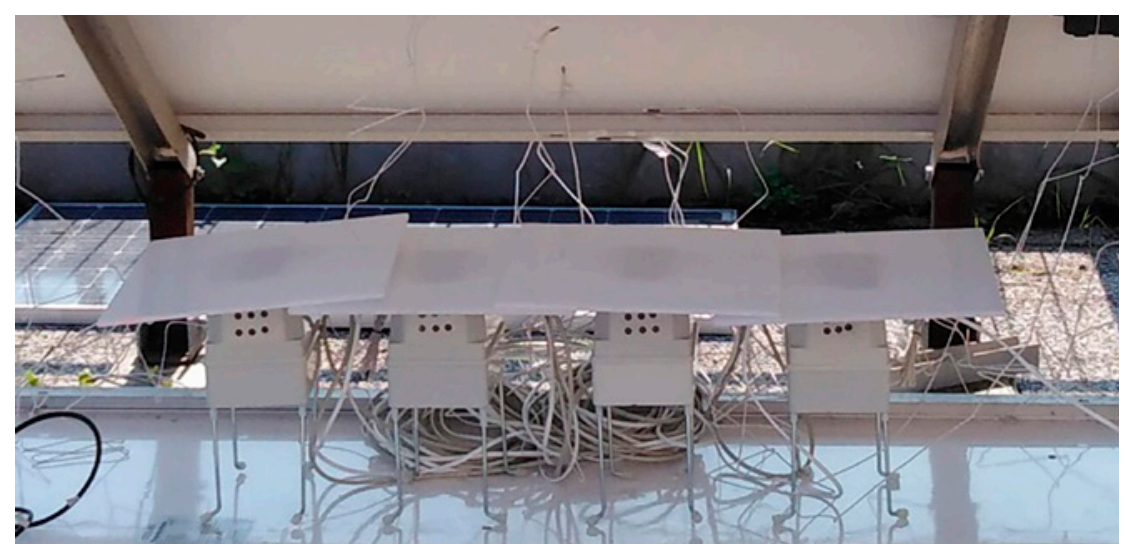

Fig. 1 Measuring system for temperature identification of PV modules

Contact address: Matúš Bilčík, Slovak University of Agriculture in Nitra, Faculty of Engineering, Department of Physics, Tr. Andreja Hlinku 2, 94976 Nitra, Slovak Republic, e-mail: bilcikmatus@gmail.com 


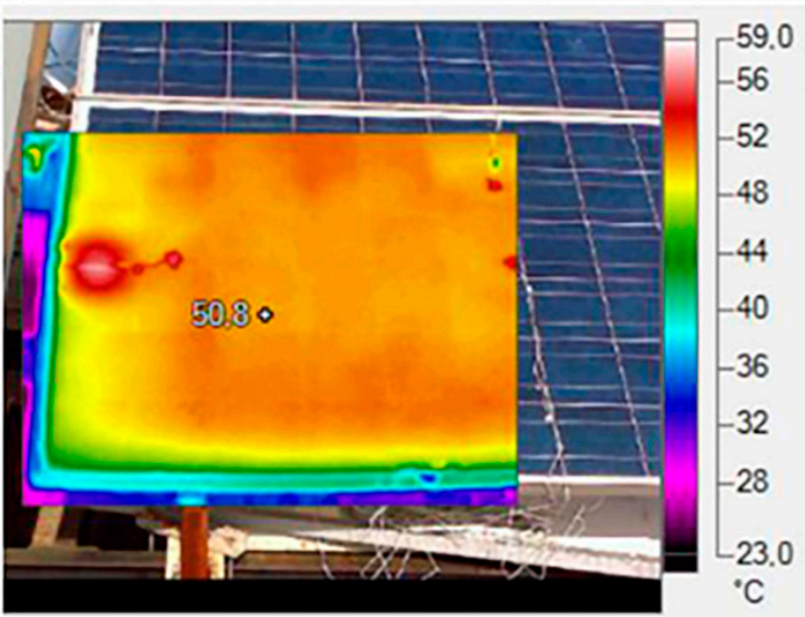

Fig. 2 Identification of temperature changes by thermocamera Fluke TiR1

contains measuring components and controller from producer ( $B \& R$, Austria) and it works fully automatically with the software programmed in Automation Studio.

The PV module consists of several components made of different materials; therefore, it is necessary to measure the temperature of the individual components of the PV module, the measuring system thereby has 24 temperature sensors with accuracy $\pm 0.75 \%$. For the purpose of comparison of temperature measurements, detection of temperature changes in the PV module surface was also realized utilizing thermocamera Fluke TiR1 (Fluke Corporation, USA). On the basis of thermovision evaluation, it is clear that the different parts of the PV module showed different temperatures (Fig. 2).

Climatic data were monitored by weather station installed at the Czech University of Life Sciences in Prague. The ambient temperature (air temperature), air humidity, air pressure, rainfall, wind velocity, direction of wind and the global solar radiation were measured by a local weather station. The ambient temperature was measured using sensor HMP45C manufactured by Vaisala Inc. (Finland), the measurement accuracy of sensor is $\pm 0.5^{\circ} \mathrm{C}$. The intensity of global solar radiation was monitored by pyranometer CM11 (Kipp \& Zonen, USA). The main experiment was performed on polycrystalline and monocrystalline PV modules. Technical parameters of these PV modules are presented in Table 1. Polycrystalline PV modules tend to have a slightly lower heat tolerance than monocrystalline solar modules, meaning that they show a slightly worse performance under high temperatures in contrast to monocrystalline modules. Theory (Kafui et al., 2018) and practice have proved that heat can affect the performance of solar modules and shorten their lifespans.

\section{Results and discussion}

Relations for temperature, and solar radiation, as well as temperature dependencies, were obtained in these research experiments; research results are presented by graphical dependencies. Experimental measurements included monitoring of temperature of PV modules' active parts; temperature of non-active white parts of PV modules, and temperature of the PV module frames. Firstly, differences between temperatures of upper and lower parts of PV module were identified utilizing thermocamera; following experiments included measurements of the temperatures of these PV module parts. On the basis of measured data, temperature dependencies were produced (Figs. 3 and 4).

The main aim of this research is creating the simplified mathematical model for the temperature and solar radiation during the time range when the solar production of electrical energy by PV system culminates during the day. The modelled mathematical dependencies can be used for prediction of the PV module operational parameters. From the mathematical description point of view, it was necessary to smooth out the extreme parts of the temperature graphical dependencies by applying appropriate procedure.

Appropriate procedure eliminates the extremes of graphical dependencies not corresponding with the assumed trend of the graphical dependencies. This procedure was used for all measured dependencies. After its application, graphs (Figs. 5 and 6) with smooth curves were plotted; these can be described by nonlinear mathematical function. The next step in graphical dependencies processing was regression analysis. It allowed the selection of the most suitable graphical dependence. On the basis of the descriptive characteristics of graphical dependencies (coefficients of regression equation, coefficients of determination etc.), the second-degree polynomial function (Eq. 1) was selected for all cases.

$$
T=A t^{2}+B t+C
$$

Table 1 Technical parameters of PV modules

\begin{tabular}{|l||c|c|}
\hline \multicolumn{1}{|l||}{ Type } & Polycrystalline & Monocrystalline \\
\hline \hline Efficiency (\%) & 14 & 17 \\
\hline Brand & Yingli Solar & Sun-Earth \\
\hline Module type & YL230P-29b & $125^{*} 125-\mathrm{F}$ \\
\hline Rated maximum power (W) & 230 & 170 \\
\hline Rated voltage (V) & 29.5 & 35.4 \\
\hline Rated current (A) & 7.8 & 4.8 \\
\hline Size $(\mathbf{m m})$ & $1590 \times 990 \times 45$ & $1590 \times 808 \times 42$ \\
\hline
\end{tabular}


where:

$T$ - temperature of PV module part $t$-time

The coefficients of regression equations and coefficients of determinations are presented in Table 2.

In experiments presented, polynomial function for temperature

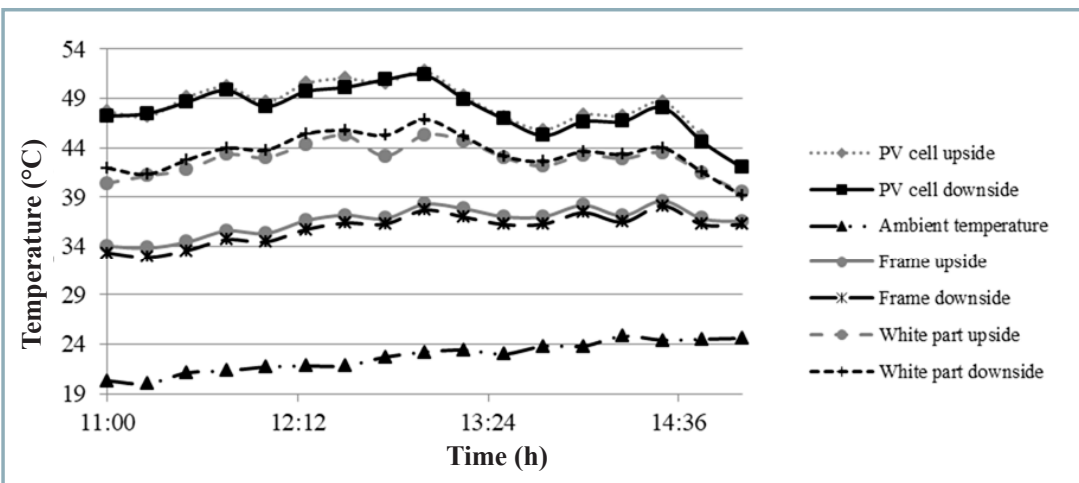

Fig. 3 Real temperature dependencies for different parts of polycrystalline PV module and ambient temperature

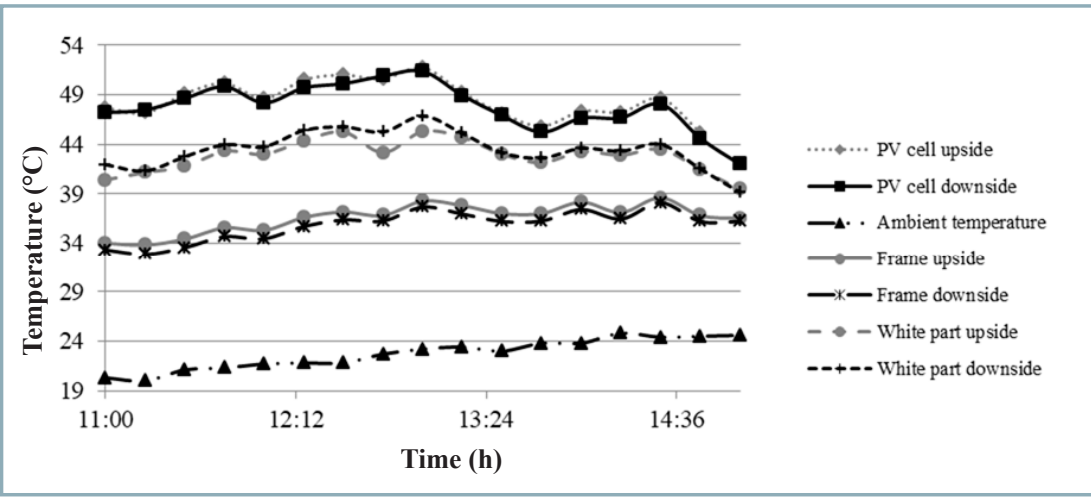

Fig. 4 Real temperature dependencies for different parts of monocrystalline PV module and ambient temperature relations was obtained. However, various authors (Amstrong and Hurley, 2010; Jones and Underwood, 2001; Schott, 1985; Servant, 1985) presented temperature relations with linear or exponential shape. This difference between the results presented in literature and experimentally obtained results can be caused by a certain ambivalence in meaning in terms of using the expression "the temperature of PV cell". Aforementioned authors measured the temperature of PV cell, yet considering the theory, there is a difference between temperature of the PV cell and temperature of the PV cell surface. These experiments monitored the temperature of PV cell surface, because the temperature measurement inside the PV cell is technically difficult to realize under the real operational conditions.

Determination coefficients are relatively high, their values are in the range $R^{2}=0.85-0.97$. The polynomial function of the second degree was selected correctly, not only from the mathematical point of view but also from the point of view of physical theory that predicts the polynomial progress of temperature in relation to the culmination of the sun's intensity.

The second aim of this research was to identify the influence of the ambient temperature on the temperature of different parts of PV module, so there was performed correlation analysis on all graphical dependencies. The results of correlation analysis are presented in Table 2 as coefficients of correlation and degrees of correlation. The correlation coefficients were found in the range from -0.36 to 0.7 . The temperature of both $\mathrm{PV}$ module frames and ambient temperature correlate to a high degree, with a correlation coefficient 0.7 . The temperature of other polycrystalline PV module parts correlates to a lesser degree. The correlation coefficient of -0.36 was found for correlation between the ambient temperature and temperature of the monocrystalline PV cell surface,

Table 2 Regression coefficients and correlation coefficients for temperature relations

\begin{tabular}{|c|c|c|c|c|c|c|}
\hline \multirow{2}{*}{$\begin{array}{l}\text { Part of PV } \\
\text { module }\end{array}$} & \multicolumn{3}{|c|}{ Coefficients of the regression equations } & \multirow{2}{*}{$\begin{array}{l}\text { Coefficients of } \\
\text { determinations }\end{array}$} & \multirow{2}{*}{$\begin{array}{l}\text { Coefficient of } \\
\text { correlation }\end{array}$} & \multirow[t]{2}{*}{ Correlation } \\
\hline & A & B & C & & & \\
\hline \multicolumn{7}{|c|}{ Polycrystalline PV module } \\
\hline PV cells & -1035.70 & 1101.40 & -240.06 & 0.97 & 0.34 & mild \\
\hline Frame & -642.80 & 699.13 & -149.84 & 0.97 & 0.70 & high \\
\hline White part & -814.68 & 865.29 & -181.27 & 0.98 & 0.32 & mild \\
\hline \multicolumn{7}{|c|}{ Monocrystalline PV module } \\
\hline PV cells & -822.91 & 874.38 & -181.20 & 0.85 & -0.36 & any \\
\hline Frame & -474.47 & 538.63 & -113.84 & 0.96 & 0.70 & high \\
\hline White part & -751.88 & 812.78 & -181.20 & 0.97 & 0.04 & low \\
\hline
\end{tabular}




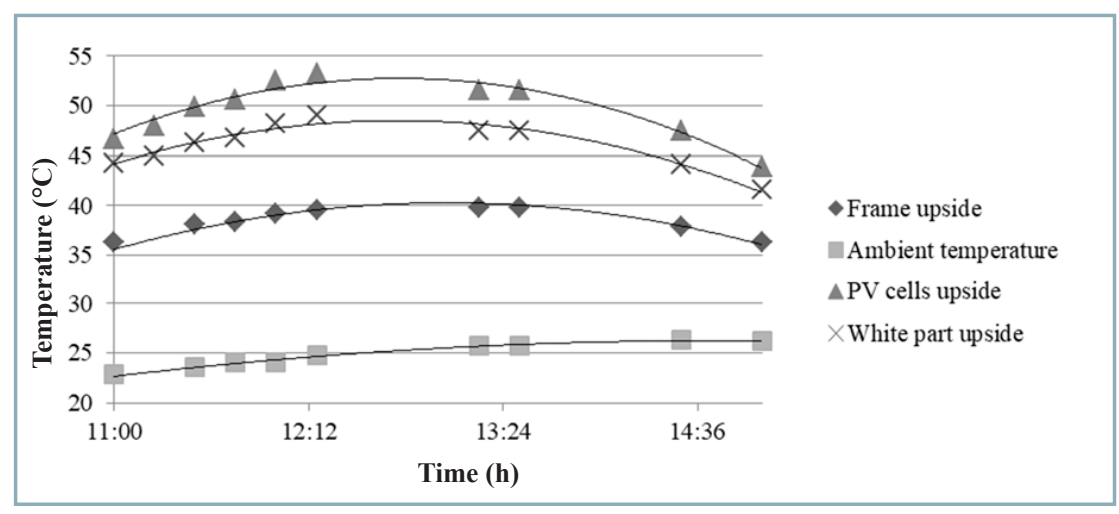

Fig. 5 Temperature dependencies for different parts of polycrystalline PV module and ambient temperature after appropriate procedure application and regression analysis

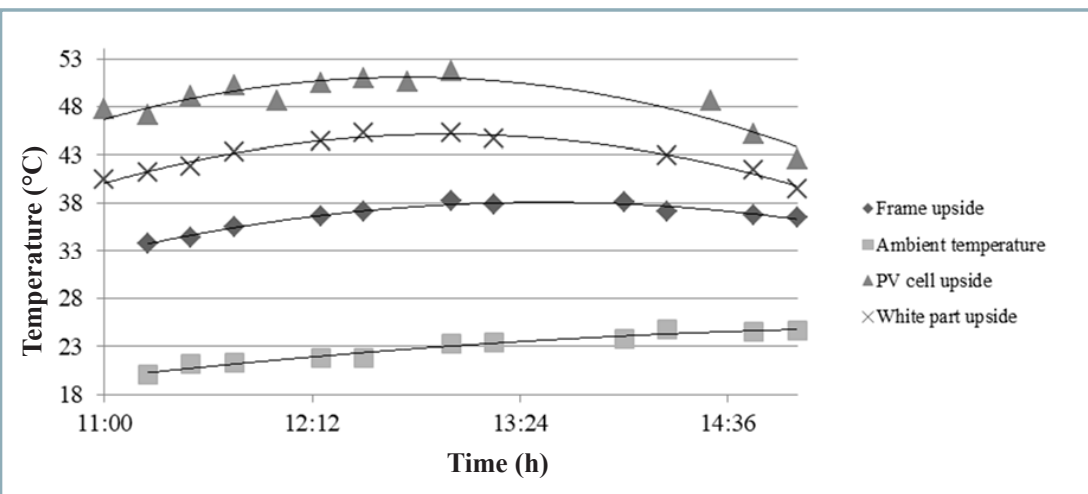

Fig. 6 Temperature dependencies for different parts of monocrystalline PV module and ambient temperature after appropriate procedure application and regression analysis

meaning that there is no correlation and mathematical dependence between the temperature of monocrystalline PV cell surface and ambient temperature. Correlation coefficient 0.039 was observed for the relation between the temperature of white area and the ambient temperature. This correlation coefficient means a low degree of correlation.
Next part presents the temperature and solar radiation dependencies. The fluctuations in the intensity of sunshine due to cloudiness change are showed in Figs. 7 and 8. These solar radiation intensity fluctuations also have influence on PV cell surface temperature. The extremes observed in real dependencies were eliminated by application of the fitting procedure.
After fitting procedure application, graphs with smooth curves (Figs. 9 and 10) were plotted and a polynomial function of a second degree was selected as a model regression equation via regression analysis. The polynomial function of a second degree is appropriate from the theoretical and practical point of view.

These functions are generally represented by a regression equation (Eq. 2).

$$
I=E t^{2}+F t+G
$$

where:

$$
\begin{array}{ll}
l & - \text { intensity of solar radiation } \\
t & - \text { time }
\end{array}
$$

Table 3 shows the coefficients of regression equation (Eq. 2) and the coefficients of determinations $R^{2}$ in the range $0.8-0.95$.

Correlation coefficients between the temperature of different parts of polycrystalline and monocrystalline PV modules and the solar radiation intensity ranged from 0.69 to 0.9 , indicating a high degree of correlation. Measurement results and statistical evaluation confirmed a well-known fact from literature, i.e. that the intensity of solar radiation affects the temperature of the PV module most significantly.

$$
T_{C}=T_{a}+\alpha G_{T}\left(1+\beta T_{a}\right)\left(1-\gamma v_{W}\right)
$$

Eq. 3 presents the temperature model for cell operating temperature $T_{c}$ by Servant (1985). In this model, $T_{a}$ is the ambient temperature, $G_{T}$ is the global solar radiation, $\eta c$ represents

\begin{tabular}{|c|c|c|c|c|c|c|}
\hline \multirow{2}{*}{$\begin{array}{l}\text { Part of PV } \\
\text { module }\end{array}$} & \multicolumn{3}{|c|}{ Coefficients of the regression equations } & \multirow{2}{*}{$\begin{array}{l}\text { Coefficients of } \\
\text { determinations }\end{array}$} & \multirow{2}{*}{$\begin{array}{l}\text { Coefficient of } \\
\text { correlation }\end{array}$} & \multirow[t]{2}{*}{ Correlation } \\
\hline & A & B & C & & & \\
\hline \multicolumn{7}{|c|}{ Polycrystalline PV module } \\
\hline PV cells & -844.75 & 909.13 & -192.33 & 0.80 & 0.80 & high \\
\hline Frame & -590.66 & 645.21 & -135.68 & 0.92 & 0.89 & high \\
\hline White part & -542.29 & 577.58 & -105.98 & 0.82 & 0.69 & high \\
\hline \multicolumn{7}{|c|}{ Monocrystalline PV module } \\
\hline PV cells & -828.61 & 859.49 & -172.08 & 0.91 & 0.88 & high \\
\hline Frame & -350.99 & 359.11 & -73.58 & 0.95 & 0.39 & mild \\
\hline White part & -630.92 & 676.84 & -137.13 & 0.95 & 0.90 & high \\
\hline
\end{tabular}
module electrical efficiency, and $v_{w}$ is

Table 3

Regression coefficients and correlation coefficients for time-solar radiation relations 


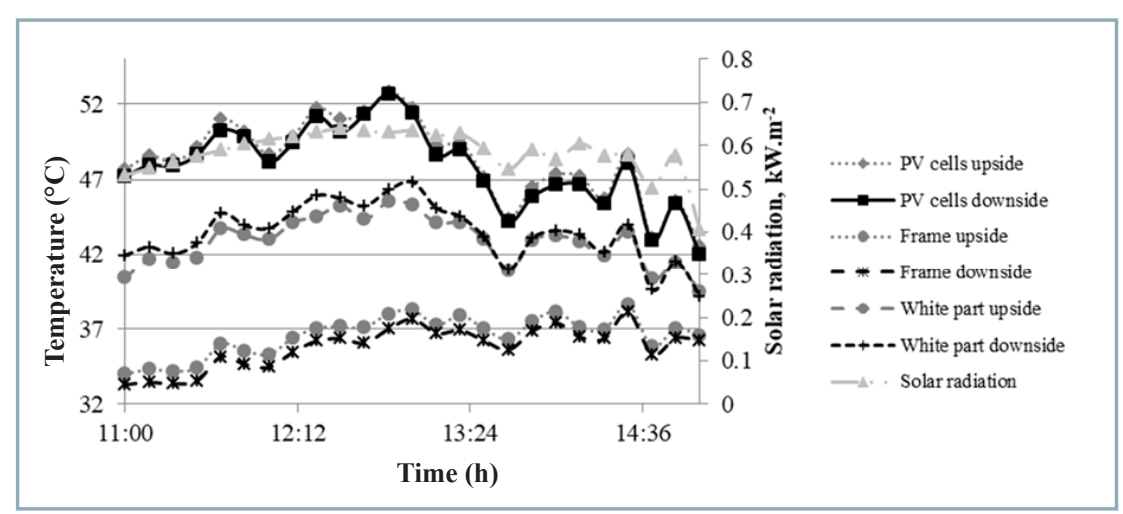

Fig. 7 Real temperature and solar radiation dependencies for different parts of polycrystalline PV module

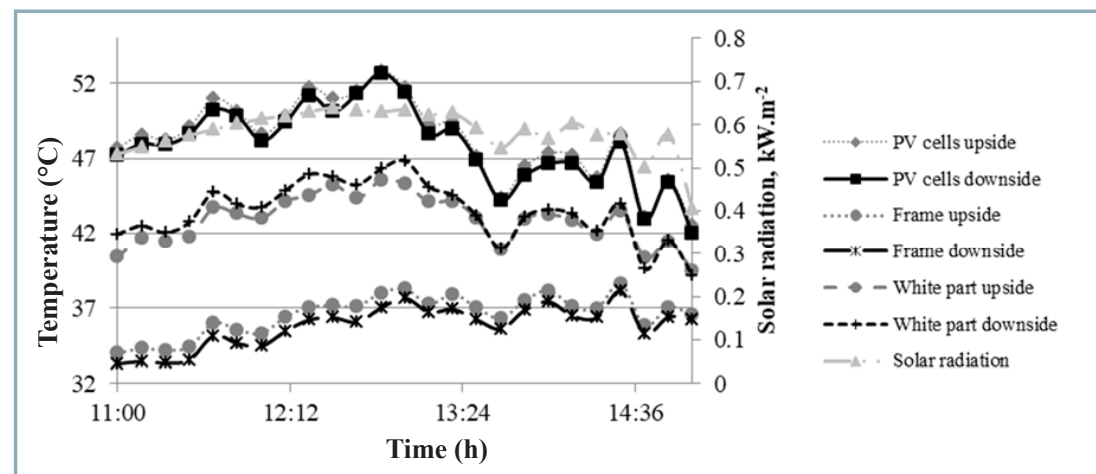

Fig. 8 Real temperature and solar radiation dependencies for different parts of monocrystaline PV module

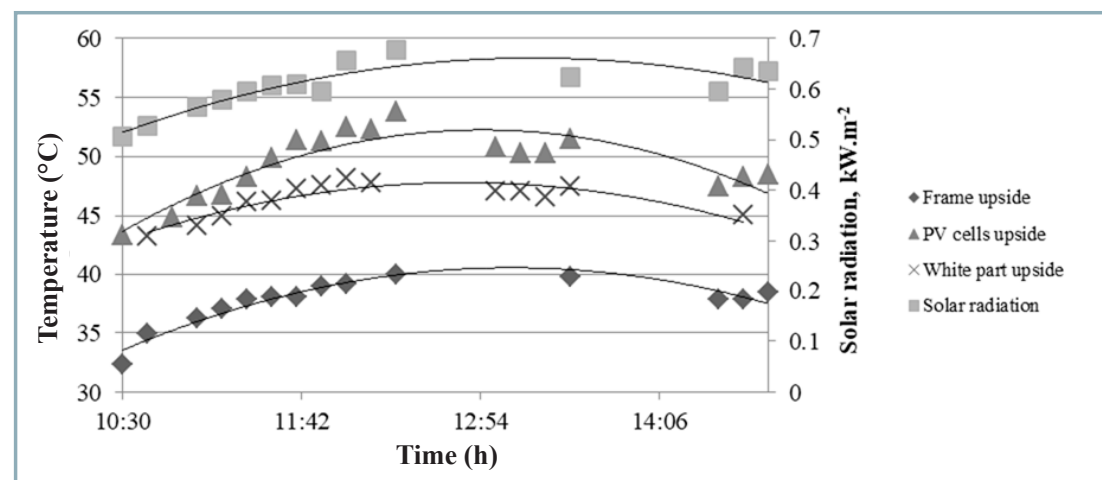

Fig. 9 Temperature dependencies of polycrystalline PV module different parts and solar radiation after application of fitting procedure and regression analysis

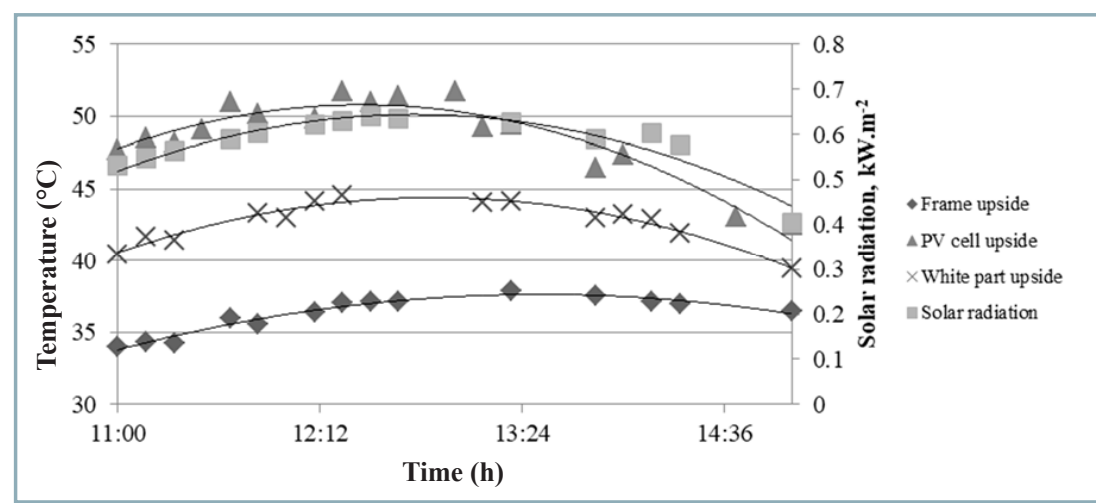

Fig. 10 Temperature dependencies of and solar radiation after application of fitting procedure and regression analysis the constant wind velocity with value $1 \mathrm{~m} \cdot \mathrm{s}^{-1}$. Values of constants by Servant (1985) in Eq. (3) are $\alpha=0.0138(-), \beta=$ $0.031(-)$, and $\gamma=0.042(-)$.

$$
\begin{gathered}
T_{C}=T_{a}+\frac{G_{T}}{G_{\text {NOCT }}} \\
\left(T_{C, \text { NOCT }}-T_{a, N O C T}\right)\left(1-\frac{\eta_{C}}{\tau \alpha}\right)
\end{gathered}
$$

The temperature model provided by Davis et al. (2001) can be described by Eq. (4); parameters and quantities are the same as in Eq. (3) except for physical quantities with lower subscript designation NOCT for the nominal operating cell temperature. The nominal operating cell temperature is defined as a temperature of a device under the conditions of the nominal terrestrial environment, where the solar radiation flux is $800 \mathrm{~W} \cdot \mathrm{m}^{-2}$. Ambient temperature is $20^{\circ} \mathrm{C}$, average wind speed is $1 \mathrm{~m} \cdot \mathrm{s}^{-1}$, electrical load is at zero (i.e. open circuit) and freestanding mounting frame is oriented regularly, to solar noon. Parameter $\alpha$ indicates the solar absorptance of PV layer and $\tau$ is transmittance of glazing. Both equations predict temperature of PV module with the linear trend. Eq. 1 is the polynomial function of the second degree and is more suitable for this purpose, because the culmination of sun intensity has polynomial trend as well.

\section{Conclusion}

On the basis of the presented results obtained in PV module temperature measurements and measurements of solar radiation intensity, it is evident that the reaction of PV module temperature is dynamic in working conditions. This fact is clear for periods during which the changes in solar radiation intensity due to cloudiness were observed. Another result in relation to the Central Europe is that temperature changes in different parts of PV modules can be characterised by polynomial function of the second degree, which was determined by the regression analysis of experimental data and by application of an appropriate procedure. The correlation analysis confirmed the significant influence of solar radiation intensity on 
temperature of polycrystalline PV module, as well as partial influence of ambient temperature on PV module temperature. The temperature of PV module depends on the material of PV module components.

\section{Acknowledgement}

This work was supported by the Slovak Ministry of Education, Science, Research, and Sport under project KEGA 017SPU4/2017 - Multimedia textbook of physics for engineers, and was co-funded by the European Community under project no 26220220180 - Building the Research Centre AgroBioTech.

\section{References}

AMSTRONG, S. - HURLEY, W. G. 2010. A thermal model for photovoltaic panels under varying atmospheric conditions. In Applied Thermal Engineering, vol. 30, pp. 1488-1495.

BILČÍK, M. - BOŽIKOVÁ, M. 2018. Wind speed and the selected time temperature dependencies for photovoltaic module In Physics - Applications and Inovations. SUA in Nitra, 145 pp. ISBN 978-80-552-1915-8.

ČORBA, Z. - KALIĆ, V. - MILIĆEVIĆ, D. 2009. Photovoltaics systems in agriculture. In Journal on Processing and Energy in Agriculture, vol. 13 , no. 4, pp. 328-331.

DAVIS, M. W. - DOUGHERTY, B. P. - FANNEY, A. H. 2001 Prediction of building integrated photovoltaic cell temperatures. In Journal of Solar Energy Engineering, vol. 123, no. 3, pp. 200-210.
CHANDER, S. - PUROHIT, A. - SHARMA, A. - NEHRA, S. P. - DHAKA, M. S. 2015. A study on photovoltaic parameters of mono-crystalline silicon solar cell with cell temperature. In Energy Reports, vol. 1, pp. 104-109.

JONES, A. D. - UNDERWOOD, C. P. 2001. A thermal model for photovoltaic systems. In Solar Energy, vol. 70, no. 4, pp. 349-359.

LIBRA, M. - POULEK, V. - KOUŘíM, P. 2017. Temperature changes of I-V characteristics on photovoltaic cells as consequence of the Fermi energy level shift. In Research in Agricultural Engineering, vol. 63, no. 1, pp. 10-15.

KAFUI, A. D. - SERES, I. - FARKAS, I. 2018. Efficiency comparison of different photovoltaic modules. In Acta Technologica Agriculturae, vol. 22, no. 1, pp. 5-11.

MALÍNEK, M. - BILČÍK, M. - BOŽIKOVÁ, M. - PETROVIĆ, A. KOTOULEK, P. - HLAVÁČ, P. 2018. The selected time temperature and wind speed dependencies for photovoltaic module. In Journal on Processing and Energy in Agriculture, vol. 22, no. 2, pp. 82-84.

MILIĆEVIĆ, D. - POPADIĆ, B. - DUMNIĆ, B. - ČORBA, Z. - KALIĆ, V. 2012. Possibility of solar potential utilization in Republic of Serbia - practical example. In Journal on Processing and Energy in Agriculture, vol. 16, no. 3, pp. 109-112.

SERVANT, J. M. 1985. Calculation of the cell temperature for photovoltaic modules from climatic data. In Bilgen, E., Hollands, K.G.T., editors. In Proceedings of the $9^{\text {th }}$ biennial congress of ISES Intersol 85, Montreal, Canada, extended abstracts, $370 \mathrm{pp}$.

SCHOTT, T. 1985. Operation temperatures of PV modules. In Proceedings of the sixth EC photovoltaic solar energy conference. London, pp. 392-396. 